\title{
Modeling and Optimization of Hard Turning Operation on 41Cr4 Alloy Steel Using Response Surface Methodology
}

\author{
Christopher Okechukwu Izelu ${ }^{1}$, Samuel Chikezie Eze ${ }^{2}$, Festus Ifeanyi Ashiedu ${ }^{1}$ \\ ${ }^{1}$ Department of Mechanical Engineering, Federal University of Petroleum Resources, Effurun, Nigeria \\ ${ }^{2}$ Samez Engineering and Consultancy Services Limited, Kaduna, Nigeria
}

Email address:

izelu.christopher@fupre.edu.ng (C. O. Izelu)

\section{To cite this article:}

Christopher Okechukwu Izelu, Samuel Chikezie Eze, Festus Ifeanyi Ashiedu. Modeling and Optimization of Hard Turning Operation on $41 \mathrm{Cr} 4$ Alloy Steel Using Response Surface Methodology. International Journal of Mechanical Engineering and Applications.

Vol. 4, No. 2, 2016, pp. 88-102. doi: 10.11648/j.ijmea.20160402.18

Received: May 3, 2016; Accepted: May 14, 2016; Published: May 30, 2016

\begin{abstract}
Product quality, productivity and organizational goodwill are often the major concern of every production or manufacturing unit. These criteria, more especially product quality, cannot readily and effectively be met through dependence on the skills of an operator. Hence, the need for optimization in order to identify the best process condition, derived from parametric combinations of process variables, for the manufacturing process. The work presented concerns an aspect of a series of hard turning experiments on $41 \mathrm{Cr} 4$ alloy structural steel conducted to model, predict and optimize the machining induced vibration, and the surface roughness as functions of the cutting speed, feed rate, and the tool nose radius. The response surface methodology, based on the central composite design of experiment is employed in the study, and analysis of the generated data performed with the aid of Design expert 9 software. A quadratic regression model was suggested as best fits for both the machining induced vibration and surface roughness data. These were confirmed by analyses of variance, which also revealed the tool nose radius and cutting speed, as well as the feed rate and cutting speed to be important factors that determine changes in the machining induced vibration and surface roughness, respectively. The optimum setting of the tool nose radius at $1.72301 \mathrm{~mm}$, feed rate at $0.15 \mathrm{~mm} / \mathrm{rev}$, and the cutting speed at $311.075 \mathrm{rev} / \mathrm{min}$ minimized the machining induced vibration to a value of $0.08 \mathrm{~mm} / \mathrm{min}^{2}$ and the surface roughness to a value of $4.74 \mu \mathrm{mm}$.
\end{abstract}

Keywords: Tool Nose Radius, Feed Rate, Cutting Speed, Machining Induced Vibration, Surface Roughness, Turning Experiment, Response Surface Methodology

\section{Introduction}

The major lathe machine operations include turning, facing, threading, and boring. However, with attachments, or any other acceptable means of improvisation, many other operations can be possible with lathe machines. These operations essentially involve surface generation with single point cutting tools. The quality of the generated surfaces is an important factor in industrial production or manufacture of machined parts. It is a function of the machining condition, and cutting tool and work-piece material and geometry. Turning process, which is of interest in this work, involves externally cylindrical surface generation. This is often achieved when a translating single point cutting tool encounters external surface of a rotating cylindrical work- piece under optimal machining conditions and other factors attributable to the used cutting tool and work-piece.

In the past, industry relied mainly on the skill and experience of operators to achieve optimal setting of work, and hence, the desired quality and performance characteristics. Later other traditional or conventional techniques [1] [2], like Taylor's tool life equation, and a number of analytical and experimental techniques for optimization evolved, and subsequently, were used to tackle the optimization problem so far with moderate level of success. Presently, attention on the same issue has shifted to the use of more accurate modern or non-conventional techniques [1] [2]. These techniques includes the fuzzy logic, scatter search technique, genetic algorithm, Taguchi technique, simulated annealing, and the response surface methodology. To some extent these techniques have been 
used in optimization of the quality and performance characteristics in the turning process. However, more research efforts are required, as new materials and process technology evolve, to ensure that industry have adequate information about products, processes and means of manufacture, and to ensure product quality, productivity and organizational goodwill are given due attention.

The purpose of this work is to model, predict and optimize the machining induced vibration $\left(V_{i}\right)$ and surface roughness $\left(R_{a}\right)$ as functions of the tool nose radius (A), feed rate (B) and cutting speed $(\mathrm{C})$ using data generated from hard turning of $41 \mathrm{Cr} 4$ alloy structural steel on a conventional lathe machine with standard cutting tool. The response surface methodology (RSM), based on the central composite (CC) design of experiment (DOE) was used, and the data generated from the turning experiment were analyzed using the Design Expert 9.0.6.2 software.

The work was supported by the works of Ozcakar and Kasapoglu [3], Abhang and Hameedullah [4], Sahoo [5], Abhang and Hameedullah [6], Sastry and Devi [7], Srinivasan et al [8], Ramudu and Sastry [9], Aruna and Dhanalaksmi [10], Chomsamutr and Jongprasithporn [11], Abhang and Hameedullah [12], Manu et al [13], Makadia and Nanavati [14], Kannan et al [15], Phate and Tatwawadi [16], Bhuiyan and Ahmed [17], Manohar et al [18], Thiyagu et al [19], Saini and Parkash [20], Saini et al [21], Soni et al [22], Shunmugesh et al [23], Kumar [24], Sastry et al [25], Revankar et al [26], Mahajan et al [27], Shihab et al [28], Gupta and Kohli [29], Khan et al [30], Devkumar et al [31], Devi et al [32], Rajpoot et al [33], Khidhir et al [34], Agrawal et al [35], Ranganath et al [36], and Chandra and Prasad [37]. The response surface methodology (RSM), as used in these works, was based on a variety of approach on design of experiment, and the generated data analyzed in a variety of software environment. A variety of work-piece materials, cutting tools, lathe machines, and parameter measurement instruments were considered. A variety of process variables and constants, and performance variables were investigated. However, results obtained from surface roughness data are in close semblance. Besides, the study is supported by the work of Kassab and Khoshnaw [38], Han et al [39], Cahuc et al [40], Delijaicov et al [41], Rogov and siamak [42], [43], which considered essentially the machining induced vibration of either the cutting tool or work-piece as the response variable.

\section{Materials, Equipment and Method}

\subsection{Work-Piece}

Chemical analysis and mechanical tests were conducted on the selected work-piece material using the laboratory at Standards Organization of Nigeria, Emene, Enugu and the observed chemical composition and mechanical properties recorded as given Tables 1 and 2. The test results revealed work-piece material to be $41 \mathrm{Cr} 4$ quenched and tempered
(QT) alloy special steel, with material number as 1.7035 . Its equivalent grades were found to be SAE-AISI 5140, BS 530M40, EN 10083-3 or EN18, and VC140. In comparison, they have no semblance with those previously investigated. A technical report by FUHONG on special steels claims $41 \mathrm{Cr} 4$ to be one of the most widely used alloy steel, more specifically, for driving elements like crankshafts, front vehicle axles, axle journals and steering components. It is also seen as having good overall mechanical properties, low temperature impact toughness and hardenability after quenching and tempering (QT) heat treatment; and higher fatigue strength after oil cooling. The machinability of this material is good when subjected to normalizing and QT conditions, but its weldability is not good, and as a result, cannot easily be processed when subjected to welding conditions. For the turning experiment, specimen workpiece of this material, given in Fig. 1, are round bars having dimensions of diameter, $25 \mathrm{~mm}$, and length, $150 \mathrm{~mm}$.

Table 1. Chemical composition of $41 \mathrm{Cr} 4$ alloy special steel.

\begin{tabular}{|c|c|c|c|c|c|}
\hline \multirow{2}{*}{$\begin{array}{l}\text { Quality of } \\
\text { material }\end{array}$} & \multirow{2}{*}{$\begin{array}{l}\text { Type of } \\
\text { material }\end{array}$} & \multicolumn{4}{|c|}{ Average elements \% } \\
\hline & & $\begin{array}{l}\text { Carbon } \\
\text { (C) }\end{array}$ & $\begin{array}{l}\text { Silicon } \\
\text { (Si) }\end{array}$ & $\begin{array}{l}\text { Manganese } \\
\text { (Mn) }\end{array}$ & $\begin{array}{l}\text { Chromium } \\
\text { (Cr) }\end{array}$ \\
\hline $\begin{array}{l}\text { Quenched and } \\
\text { Tempered Steel }\end{array}$ & $41 \mathrm{Cr} 4$ & 0.40 & 0.25 & 0.65 & 1.00 \\
\hline
\end{tabular}

Table 2. Mechanical properties of $41 \mathrm{Cr} 4$ alloy special steel.

\begin{tabular}{llllll}
\hline Sample ID & $\begin{array}{l}\text { Diameter } \\
(\mathbf{m m})\end{array}$ & $\begin{array}{l}\text { Area } \\
\left(\mathbf{m m}^{\mathbf{2}}\right)\end{array}$ & BHN & $\begin{array}{l}\text { Peak } \\
\text { load }(\mathbf{k N})\end{array}$ & $\begin{array}{l}\mathbf{U}_{\text {ts }} \\
\mathbf{N} / \mathbf{m m}^{2}\end{array}$ \\
\hline Solid, Round & 10.00 & 78.55 & 278.48 & 70.92 & 902.83 \\
\hline
\end{tabular}

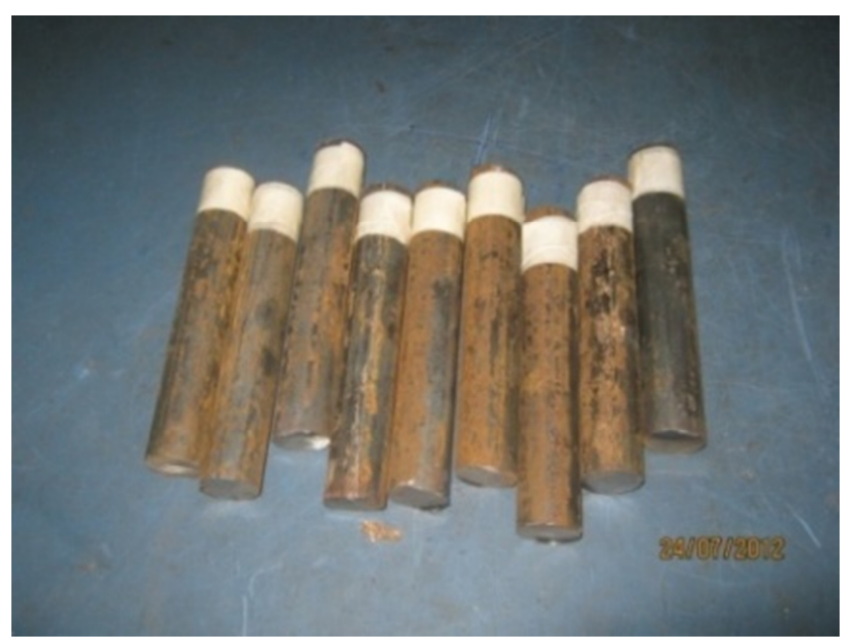

Figure 1. Samples of $41 \mathrm{Cr} 4$ Alloy Steel Bars.

\subsection{Processing Equipment}

An engine lathe of the type YUCY6240B, with serial number, 2008031074 (Fig. 2a), and a carbide cutting tool of the type F30 (Fig. 2b) were used in the turning experiment. The overall dimensions of the tool insert is $25 \mathrm{~mm} \mathrm{x} 25 \mathrm{~mm}$ $\mathrm{x} 12.5 \mathrm{~mm}$. Its back rake angle is $10^{\circ}$, side rake angle is $12^{\circ}$, side relief angle is $5^{\circ}$ and side cutting edge angle is $15^{\circ}$. 


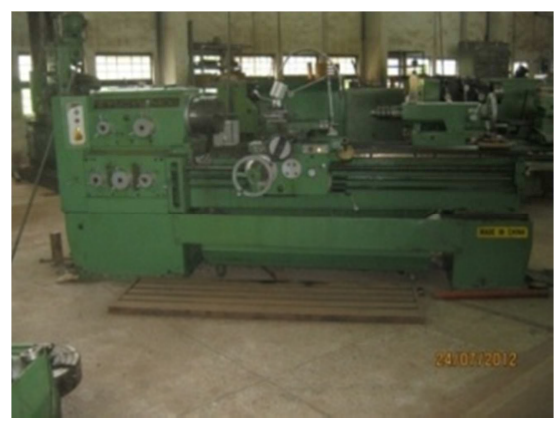

(a)

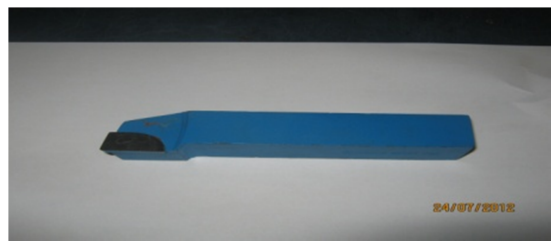

(b)

Figure 2. (a) Conventional lathe machine, YUCY6240B; (b) Cutting tool with carbide insert, F30.

\subsection{Process Variables}

The tool nose radius (A), feed rate (B) and cutting speed (C) are the selected process variables. Others were kept constant within experimental limits. The tool nose radius (A) [mm] is the radius of the tool at its cutting point. Feed rate (B) $[\mathrm{mm} / \mathrm{rev}]$ is the speed of the cutting tool relative to that of the work-piece as the tool takes a cut along the axis of the work-piece. The cutting speed (C) [rev/min] is the rotational speed of the lathe machine spindle or the work-piece. The extent to which these variables influence the surface roughness $\left(R_{a}\right)$ and machining induced vibration $\left(V_{i}\right)$, is being investigated. To improve on quality of the machined part, the process variables $\mathrm{A}, \mathrm{B}$ and $\mathrm{C}$ can be set within limits (Table 3 ) as to minimize $R_{a}$ and $V_{i}$.

Table 3. Levels of the input variables.

\begin{tabular}{lllllll}
\hline \multirow{2}{*}{ S/N } & \multirow{2}{*}{ Parameters } & \multirow{2}{*}{ Notation } & \multirow{2}{*}{ Unit } & \multicolumn{3}{l}{ Levels } \\
\cline { 5 - 7 } & & & Low & Medium & High \\
\hline 1 & Tool Nose Radius & A & {$[\mathrm{mm}]$} & 0 & 1 & 2 \\
2 & Feed rate & B & {$[\mathrm{mm} / \mathrm{rev}]$} & 0.15 & 0.225 & 0.30 \\
3 & Cutting Speed & C & {$[$ rev per min $]$} & 260 & 330 & 400 \\
\hline
\end{tabular}

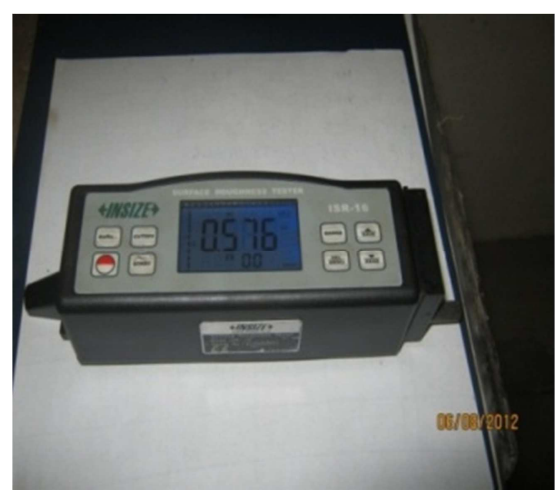

(a)

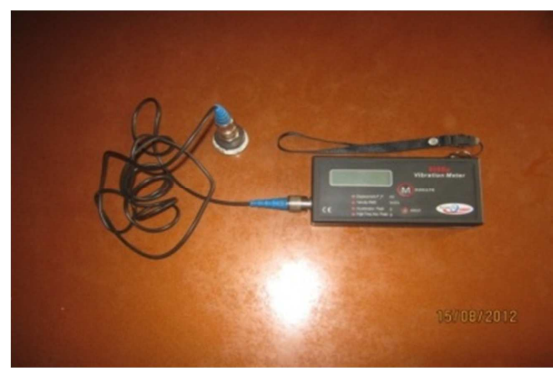

(b)

Figure 3. (a) Surface roughness tester, ISR-16; (b) Vibration meter with transducer, $908 \mathrm{BE}$.

\subsection{Response Variables}

The surface roughness $\left(R_{a}\right)$ and machining induced vibration $\left(V_{i}\right)$ are the selected response variables.

\subsubsection{Surface Roughness}

The surface roughness $\left(R_{a}\right)$, as a measure of surface texture [2], is the vertical deviations of a real surface from its ideal form. A large deviation is taken as a rough surface, while a small deviation is taken as a smooth surface. Thus, surface roughness is seen as the high frequency, short wavelength component of a measured surface, which determines how a real object will interact with its environment. Rough surfaces wear faster and have higher coefficient of friction than smooth surfaces. Again, roughness of a surface [micron, $\mu \mathrm{m}$, or $\mu \mathrm{mm}$ ] may form nucleation sites for cracks or corrosion, promote adhesion, and may be very expensive to control in manufacturing. In this study, an inside surface roughness tester, ISR-16, such as given in Fig. 3a was use to undertake measurement of the surface roughness. It was taken at three different positions located at $120^{\circ}$ on the surface and about the axis of the work-pieces. The surface texture of the turned surface is taken to be the average of these values. Surface roughness $\left(R_{a}\right)[\mu \mathrm{m}]$ is the center line average roughness [5], also known as, the arithmetic deviation of the surface height from the mean line through the profile, which separates the profile above and below it by equal area.

\subsubsection{Machining Induced Vibration}

The four different ways vibrations may occur, during turning and allied lathe operations, include (a) sudden clash of a tool against a work-piece, (b) irregular tissues of the work-piece, (c) regular excitation due to asymmetric torque, and (d) due to bearing defects. The machining induced vibration is related to a sudden clash of a tool against a work-piece, also known as self-excited vibration. It occurs at the cutting zone due to interaction of the cutting tool, chips, and the work-piece. It is referred to as chatter [38], [39], [40], especially, when it is excessive. As chatter it can produce (a) a defective machined surface, and (b) an excessive wear and breakage of the cutting tool. It influences the surface roughness of machined components significantly [41], [42], [43]. Essentially, machining induced vibration cannot be manipulated or controlled. 
However, it can be measured, and therefore, may be treated as a response variable, in the form of an acceleration amplitude $\left[\mathrm{m} / \mathrm{min}^{2}\right]$. A vibration meter with transducer, type 908 BE (Fig. 3b) is selected for its measurement. The level of tool vibration was determined by a vertical data of a transducer mounted near to the tip and connected to the vibration meter. The amplitude of displacement and velocity of the point on the cutting tool constituted the data for each sample. The relation between the displacement, velocity and acceleration was thereafter used to calculate the amplitude of acceleration.

\subsection{Design of Experiment and Method of Data Analysis}

Like most techniques of design of experiment, RSM attempts to minimize the number of runs or trials, optimize values of parameters, assess experimental error, make qualitative estimation of parameters, and to make inference regarding the effect of parameters on the characteristics of a process [1]. For this reasons, RSM, based on CC-DOE, was selected. Therefore, it is use in this work to model, predict and optimize $R_{a}$ and $V_{i}$ as functions of the process variables, A, B and C. As a mathematical and statistical technique, it is developed for the treatment of problems involving a response of interest as a function of several variables [5]. It is one of the ways machining process modeling and analysis can be achieved to facilitate its optimization. Its application requires machining response $Y$ to be defined as: $Y=\varphi\left(x_{1}, x_{2}, \ldots, x_{i}\right) \pm e$, where $\varphi\left(x_{1}, x_{2}, \ldots, x_{i}\right)$ is the response surface function in the form of a polynomial model, $x_{i}$ are the process variables and $e$ is the residual or experimental error. The second order polynomial or quadratic model may, therefore, be written as:

$$
\begin{aligned}
\varphi & =\varphi\left(x_{1}, x_{2}, \ldots, x_{k}\right) \\
& =(Y \pm e) \\
& =b_{0}+\sum_{i=1}^{k} b_{i} x_{i}+\sum_{i=1}^{k} b_{i i} x_{i}^{2}+\sum_{i=1}^{k} b_{i j} x_{i} x_{j}
\end{aligned}
$$

Equation (1) is a multiple regression model. In this form, it has constant, linear, square and cross-product terms. It can, satisfactorily, be used to correlate dependent variables, $\varphi_{j}$, with independent variables, $x_{i}$. A number of techniques for DOE are available for use to estimate the coefficients of the regression models. The $\mathrm{CC}$ was selected for the design of the turning experiment. Analysis of variance (ANOVA) was used to validate the developed models, and also, to predict the effect of selected factors $\mathrm{A}, \mathrm{B}$ and $\mathrm{C}$ on the response characteristics, $V_{i}$ and $R_{a}$. Optimization of the coded and actual response functions, $V_{i}(A, B, C)$ and $R_{a}(A, B, C)$, subject to constraints as determined by the limits of the factors $\mathrm{A}, \mathrm{B}$ and $\mathrm{C}$, was performed as appropriate using standard optimization technique. The RSM was implemented in the Design Expert 9 software version 9.06 .2 environment.

\subsection{Procedure of Turning Experiment}

In the setup for turning experiment shown in Fig. 4, twenty-seven (27) specimen work-piece of $41 \mathrm{Cr} 4$ alloy steel round bars (Fig. 1) were turned on the conventional lathe (Fig. 2a) with a carbide tool insert (Fig. 2b). The run order as generated from Design Expert 9 software based on CC-DOE is given in Table 4. Measurements of $V_{i}$ data were taken three times with a vibration transducer (Fig. $3 b$ ) placed on the tool post near the cutting zone. The data was transmitted to the vibration meter (Fig. 3b), and read out as displacement and velocity. The average cutting tool acceleration was determined from the general relations between displacement, velocity and acceleration. Measurements of $R_{a}$ data were also taken at three (3) different locations, $120^{\circ}$ from each other, on the machined surface using a surface roughness tester (Fig. $3 \mathrm{a})$ and the average values were recorded. The measured $V_{i}$ and $R_{a}$ are given in Table 4 .

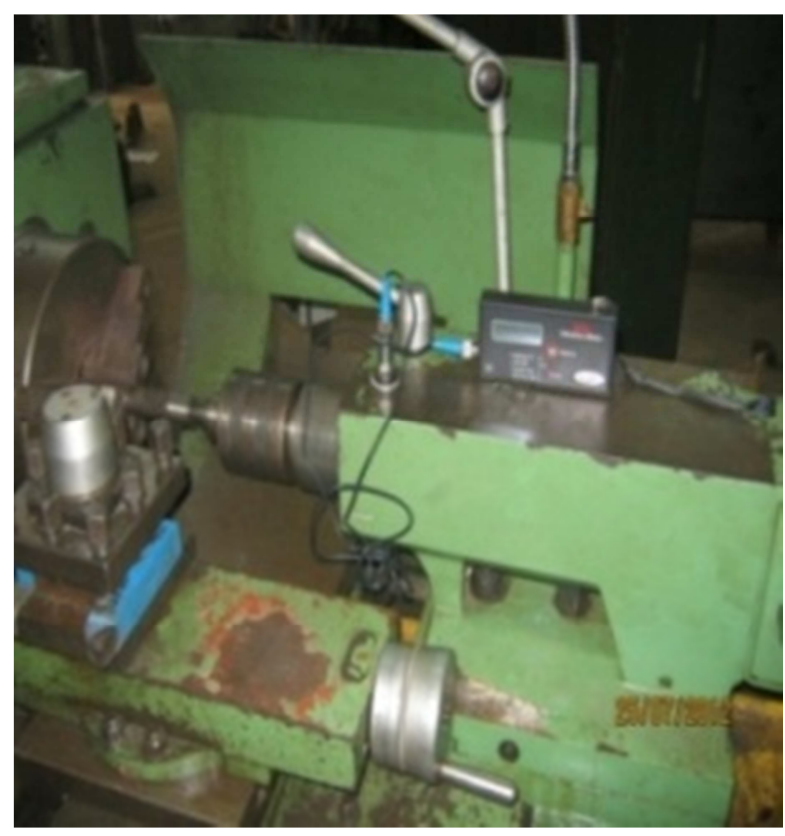

(a)

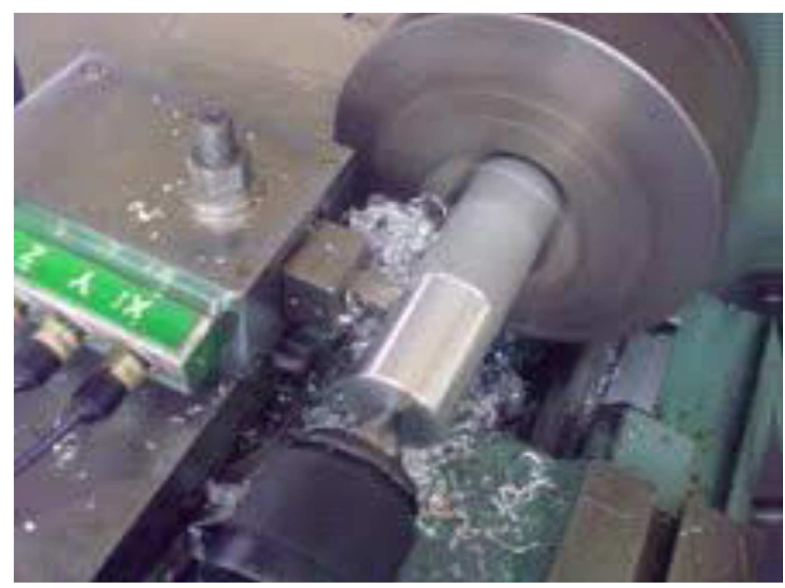

(b)

Figure 4. Setup for the turning experiment. 
Table 4. Data generated from the turning experiment.

\begin{tabular}{|c|c|c|c|c|c|c|}
\hline & & $\mathbf{A}$ & B & $\mathrm{C}$ & $V_{i}$ & $\boldsymbol{R}_{a}$ \\
\hline Standard & Run & $\begin{array}{l}\text { Tool Nose Radius } \\
{[\mathrm{mm}]}\end{array}$ & $\begin{array}{l}\text { Feed Rate [mm per } \\
\text { rev] }\end{array}$ & $\begin{array}{l}\text { Cutting Speed } \\
\text { [rev per min] }\end{array}$ & $\begin{array}{l}\text { Acceleration Amplitude } \\
\text { [mm per min square] }\end{array}$ & $\begin{array}{l}\text { Surface Roughness } \\
\text { [micro mm] }\end{array}$ \\
\hline 1 & 17 & 0 & 0.15 & 260 & 0.13 & 12.857 \\
\hline 2 & 21 & 1 & 0.15 & 260 & 0.15 & 5.602 \\
\hline 3 & 26 & 2 & 0.15 & 260 & 0.13 & 5.790 \\
\hline 4 & 19 & 0 & 0.225 & 260 & 0.23 & 13.710 \\
\hline 5 & 9 & 1 & 0.225 & 260 & 0.30 & 6.840 \\
\hline 6 & 12 & 2 & 0.225 & 260 & 0.24 & 7.524 \\
\hline 7 & 6 & 0 & 0.3 & 260 & 0.16 & 14.193 \\
\hline 8 & 23 & 1 & 0.3 & 260 & 0.20 & 9.184 \\
\hline 9 & 14 & 2 & 0.3 & 260 & 0.24 & 9.250 \\
\hline 10 & 3 & 0 & 0.15 & 330 & 0.17 & 8.213 \\
\hline 11 & 5 & 1 & 0.15 & 330 & 0.15 & 4.590 \\
\hline 12 & 22 & 2 & 0.15 & 330 & 0.05 & 6.292 \\
\hline 13 & 16 & 0 & 0.225 & 330 & 0.21 & 6.895 \\
\hline 14 & 7 & 1 & 0.225 & 330 & 0.19 & 5.115 \\
\hline 15 & 8 & 2 & 0.225 & 330 & 0.14 & 7.149 \\
\hline 16 & 27 & 0 & 0.3 & 330 & 0.09 & 8.110 \\
\hline 17 & 2 & 1 & 0.3 & 330 & 0.16 & 6.342 \\
\hline 18 & 15 & 2 & 0.3 & 330 & 0.12 & 11.080 \\
\hline 19 & 18 & 0 & 0.15 & 400 & 0.33 & 4.839 \\
\hline 20 & 20 & 1 & 0.15 & 400 & 0.25 & 5.320 \\
\hline 21 & 24 & 2 & 0.15 & 400 & 0.14 & 10.300 \\
\hline 22 & 25 & 0 & 0.225 & 400 & 0.38 & 5.870 \\
\hline 23 & 11 & 1 & 0.225 & 400 & 0.33 & 5.093 \\
\hline 24 & 4 & 2 & 0.225 & 400 & 0.22 & 12.903 \\
\hline 25 & 1 & 0 & 0.3 & 400 & 0.24 & 6.137 \\
\hline 26 & 10 & 1 & 0.3 & 400 & 0.19 & 8.418 \\
\hline 27 & 13 & 2 & 0.3 & 400 & 0.12 & 14.760 \\
\hline
\end{tabular}

\section{Results and Discussion}

Table IV shows the design layout for the turning experiment conducted as well as the response data generated. The experiment was conducted under a controlled environment to minimize error. The outcome of data analysis in the environment of the Design Expert software, version 9.0.6.2, are presented and discussed as follows:

\subsection{Machining Induced Vibration Data}

Table 5 shows that a quadratic model is suggested for the machining induced vibration data, with its accuracy comparatively predicted by the standard deviation of 0.019 and PRESS of 0.013 , and also, by the R-square of 0.9622 , adjusted R-square of 0.9421 and predicted R-square of 0.9159 . Table 6 confirms the significance of the model, and its capability for accurate prediction of $V_{i}$ within the selected limits. The significant model terms are $\mathrm{A}, \mathrm{C}, \mathrm{A}^{2}, \mathrm{~B}^{2}, \mathrm{C}^{2}, \mathrm{AB}$, $\mathrm{AC}$ and $\mathrm{BC}$. They are good predictors of the machining induce vibration $\left(V_{i}\right)$. The dominance of the influence of the linear terms on $V_{i}$ begins with $\mathrm{A}$, followed by $\mathrm{C}$, and then, $\mathrm{B}$. That of the square terms on $V_{i}$ starts with $\mathrm{B}^{2}$, followed by $\mathrm{C}^{2}$, and then $\mathrm{A}^{2}$. Also that of the cross-products terms on $V_{i}$ emanates with $\mathrm{AC}$ followed by $\mathrm{BC}$, and then, AC. Table 7, showed that the predicted R-square of 0.9159 is in reasonable agreement with the adjusted R-square of 0.9421 , since the difference of 0.0262 is less than 0.2 . The adequacy precision of 27.708 , greater than 4 , is a desirable signal to noise ratio. This indicates that there is adequate signal, and that this model can be used to navigate the design space. The models for the machining induced vibration $\left(V_{i}\right)$, given in terms of the coded and actual factors A, B and C, respectively, are as follows:

$$
\begin{gathered}
V_{i}=0.21-0.03 A+0.0011 B+0.023 C+0.025 A B-0.047 A C \\
-0.03 B C-0.028 A^{2}-0.081 B^{2}+0.079 C^{2} \\
V_{i}=0.55768+0.17056 A+8.05608 B-0.00834 C+0.33333 A B-0.00067 A C \\
-0.00571 B C-0.02778 A^{2}-14.41975 B^{2}+0.000016 C^{2}
\end{gathered}
$$

Figure 5a shows that the predicted $V_{i}$ data fits well with the actual data. Figure $5 \mathrm{~b}$ revealed the predicted $V_{i}$ to have nonlinear relationships with the tool nose radius (A), feed rate $(\mathrm{B})$, and the cutting speed (C). In terms of significance, the effect of $\mathrm{A}$ and $\mathrm{C}$ on $V_{i}$ is more at low and high levels of their values, when compared to that of $\mathrm{B} . V_{i}$ decreased continuously with increase in A. It increased with increase in $\mathrm{B}$ up to the reference point, and then decreased. It also decrease with increase in $\mathrm{C}$ to the reference point, and then, increased. The implication of the behavior is that $V_{i}$ is minimized when $\mathrm{A}$ is set at higher level of its values and $\mathrm{B}$ set at either lower or higher level of its values, while $\mathrm{C}$ is set 
at the reference point. These behaviors can also be seen in the contour and response surface plots given in Figs 6 to 8. It can as well be attributed to the observed interaction between process variables, $\mathrm{A}, \mathrm{B}$, and $\mathrm{C}$.

Table 5. Model summary statistics.

\begin{tabular}{llllll}
\hline Source & Standard. Deviation & R-Squared & Adjusted R-Squared & Predicted R-Squared & PRESS \\
\hline Linear & 0.076 & 0.1648 & 0.0559 & -0.1549 & 0.18 \\
2FI & 0.066 & 0.4463 & 0.2802 & 0.1517 & 0.13 \\
Quadratic & 0.019 & 0.9622 & 0.9421 & 0.9159 & 0.013 \\
Cubic & 0.023 & 0.9668 & 0.9137 & 0.7871 & Suggested \\
\hline
\end{tabular}

Table 6. ANOVA for response surface quadratic model for acceleration amplitude.

\begin{tabular}{|c|c|c|c|c|c|c|}
\hline Source & Sum of Squares & Degree of Freedom & Mean Square & F Value & $\begin{array}{l}\text { p-value } \\
\text { Prob }>\text { F }\end{array}$ & \\
\hline Model & 0.15 & 9 & 0.017 & 48.03 & $<0.0001$ & significant \\
\hline A-Tool Nose Radius & 0.016 & 1 & 0.016 & 46.10 & $<0.0001$ & \\
\hline B-Feed Rate & $2.222 \mathrm{E}-005$ & 1 & 2.222E-005 & 0.063 & 0.8045 & \\
\hline C-Cutting Speed & $9.800 \mathrm{E}-003$ & 1 & $9.800 \mathrm{E}-003$ & 27.89 & $<0.0001$ & \\
\hline $\mathrm{AB}$ & 7.500E-003 & 1 & 7.500E-003 & 21.34 & 0.0002 & \\
\hline $\mathrm{AC}$ & 0.026 & 1 & 0.026 & 74.37 & $<0.0001$ & \\
\hline $\mathrm{BC}$ & 0.011 & 1 & 0.011 & 30.73 & $<0.0001$ & \\
\hline $\mathrm{A}^{\wedge} 2$ & $4.630 \mathrm{E}-003$ & 1 & 4.630E-003 & 13.17 & 0.0021 & \\
\hline $\mathrm{B}^{\wedge} 2$ & 0.039 & 1 & 0.039 & 112.33 & $<0.0001$ & \\
\hline $\mathrm{C}^{\wedge} 2$ & 0.037 & 1 & 0.037 & 106.26 & $<0.0001$ & \\
\hline Residual & $5.974 \mathrm{E}-003$ & 17 & $3.514 \mathrm{E}-004$ & & & \\
\hline Cor Total & 0.16 & 26 & & & & \\
\hline
\end{tabular}

Table 7. Quadratic model statistics.

\begin{tabular}{llll}
\hline Standard Deviation & 0.019 & R-Squared & 0.9622 \\
Mean & 0.19 & Adjusted R-Squared & 0.9421 \\
C.V. \% & 9.62 & Predicted R-Squared & 0.9159 \\
PRESS & 0.013 & Adequate Precision & 27.708 \\
\hline
\end{tabular}

\section{Predicted vs. Actual}

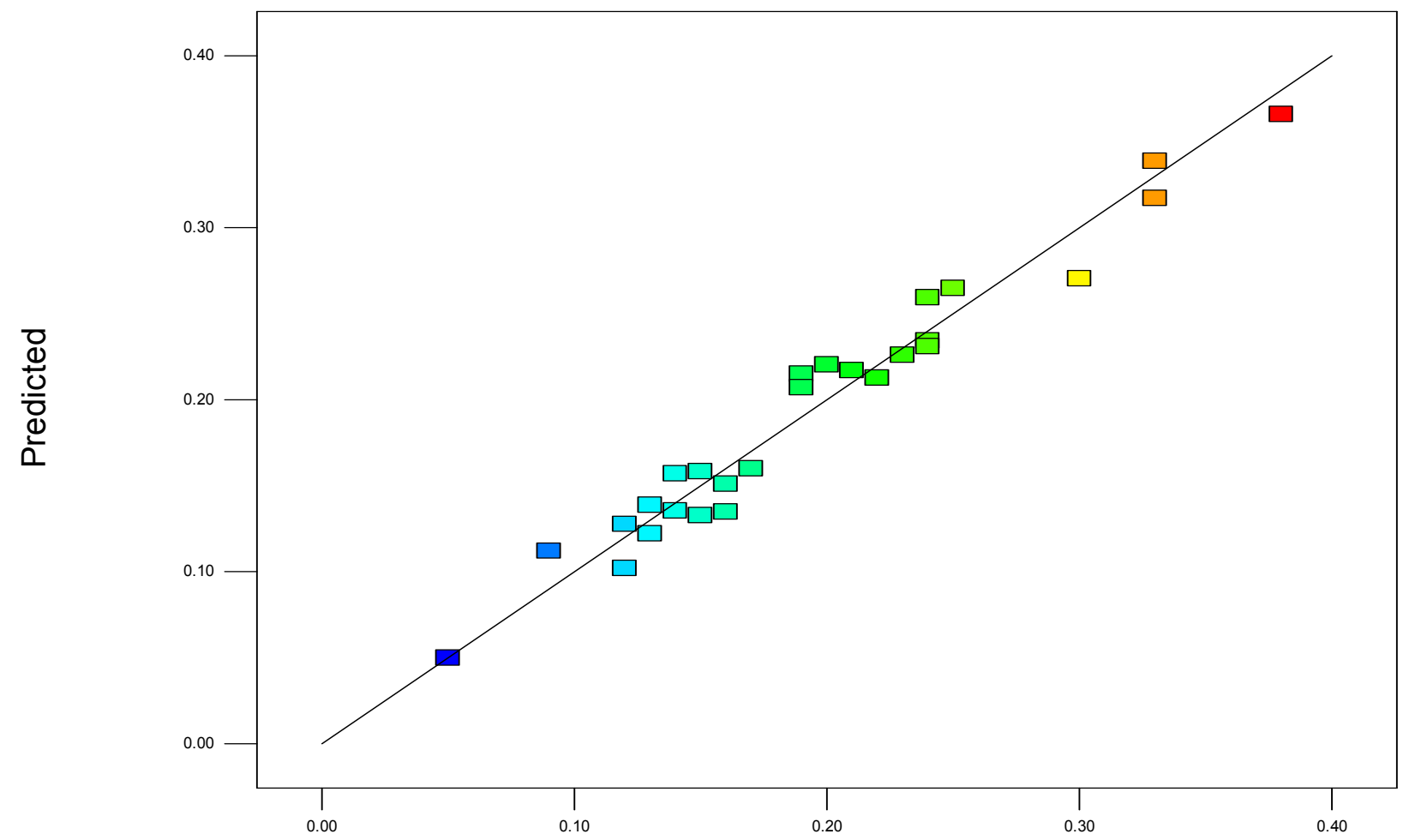




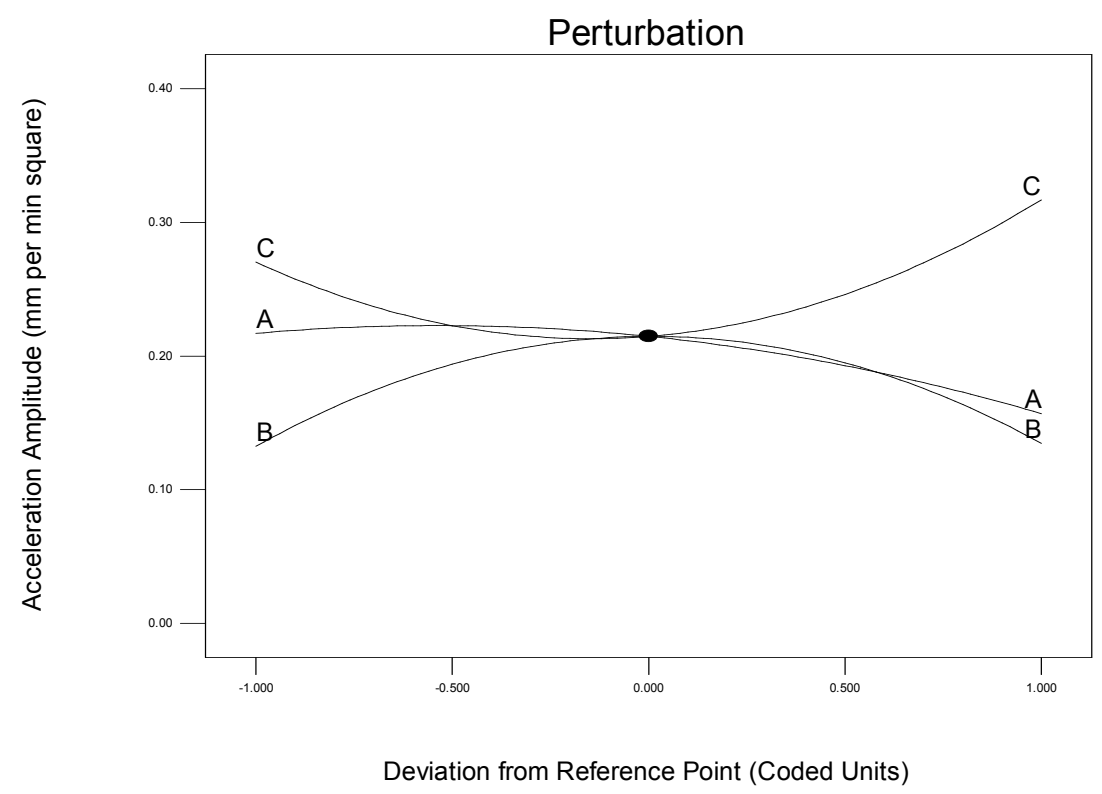

Figure 5. Predicted vs actual, and perturbation plots for $V_{i}$.

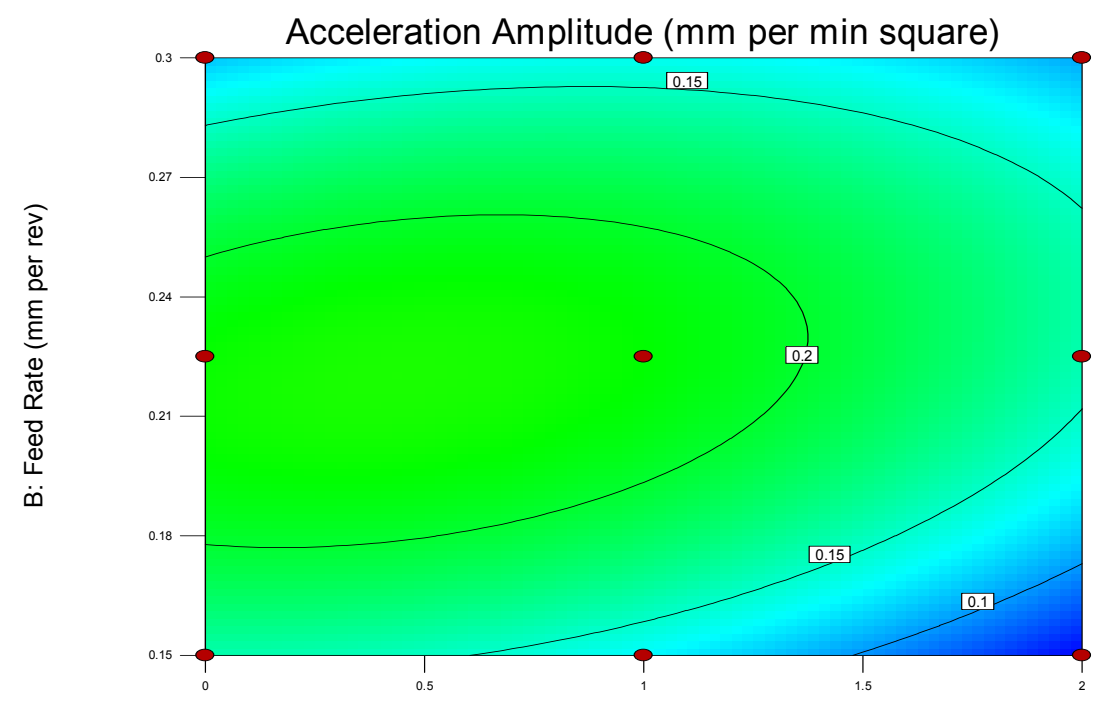

A: Tool Nose Radius ( $\mathrm{mm})$

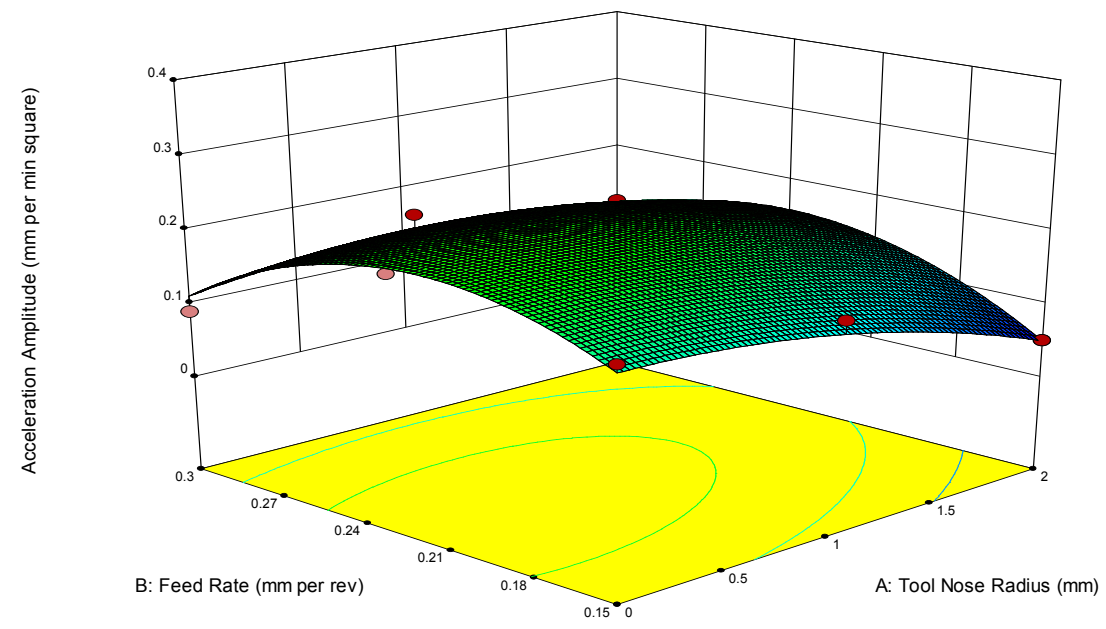

Figure 6. Contour and response surface plots of $V_{i}$ against $A$ and $B$ with $C$ set at 330 rev per min. 

Alloy Steel Using Response Surface Methodology

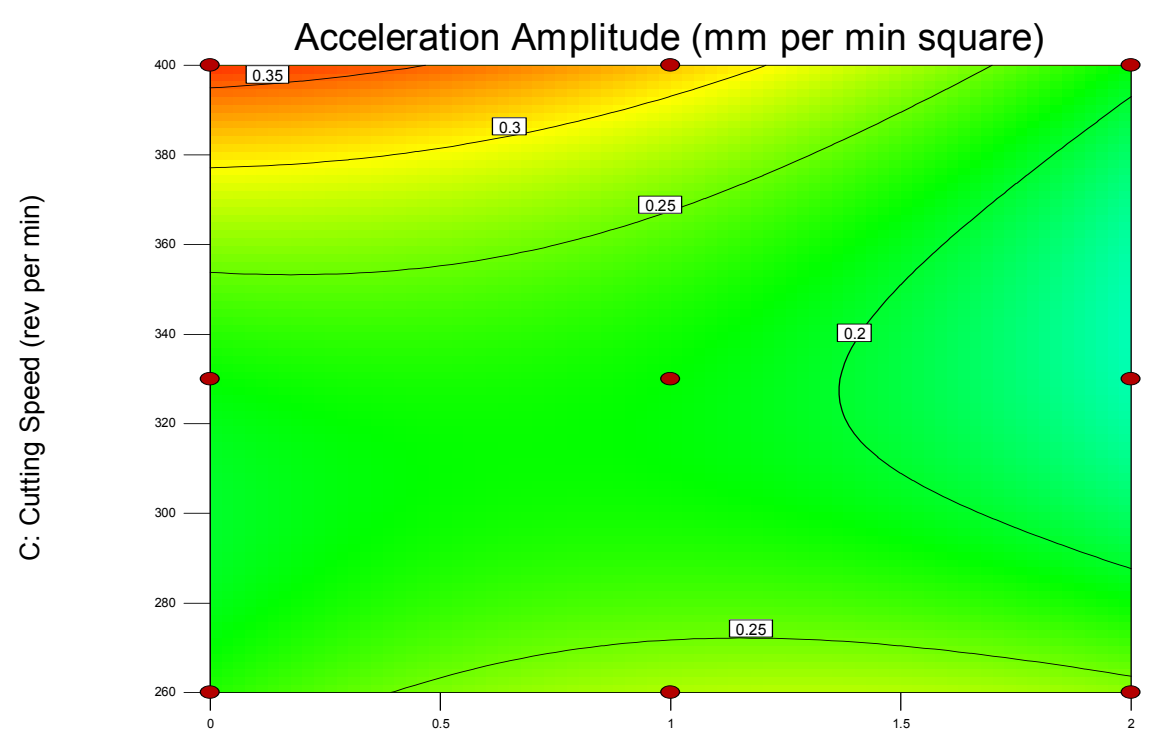

A: Tool Nose Radius ( $\mathrm{mm})$

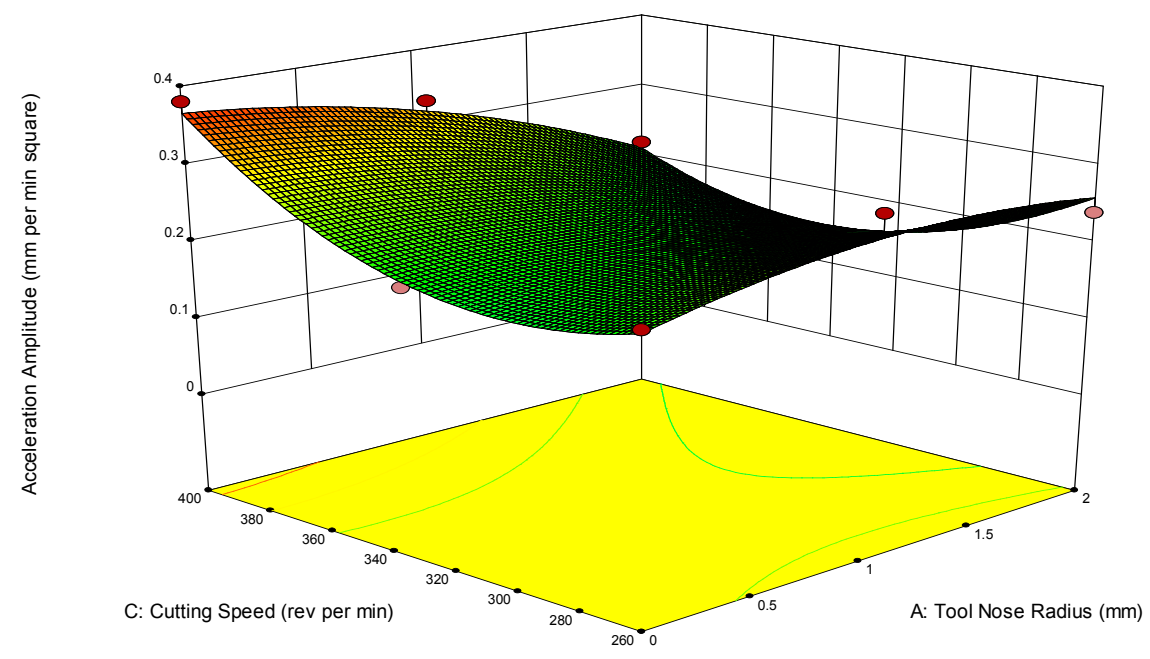

Figure 7. Contour and response surface plots of $V_{i}$ against $A$ and $C$ with $B$ set at $0.225 \mathrm{~mm} / \mathrm{rev}$.

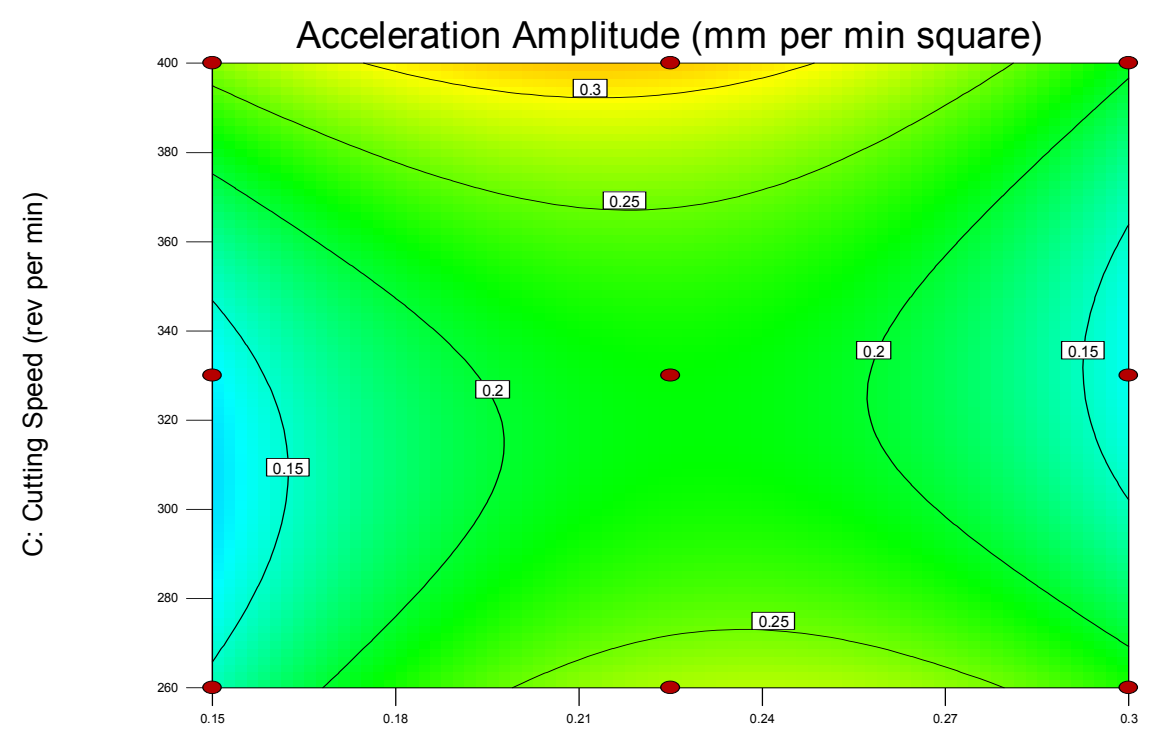

B: Feed Rate (mm per rev) 


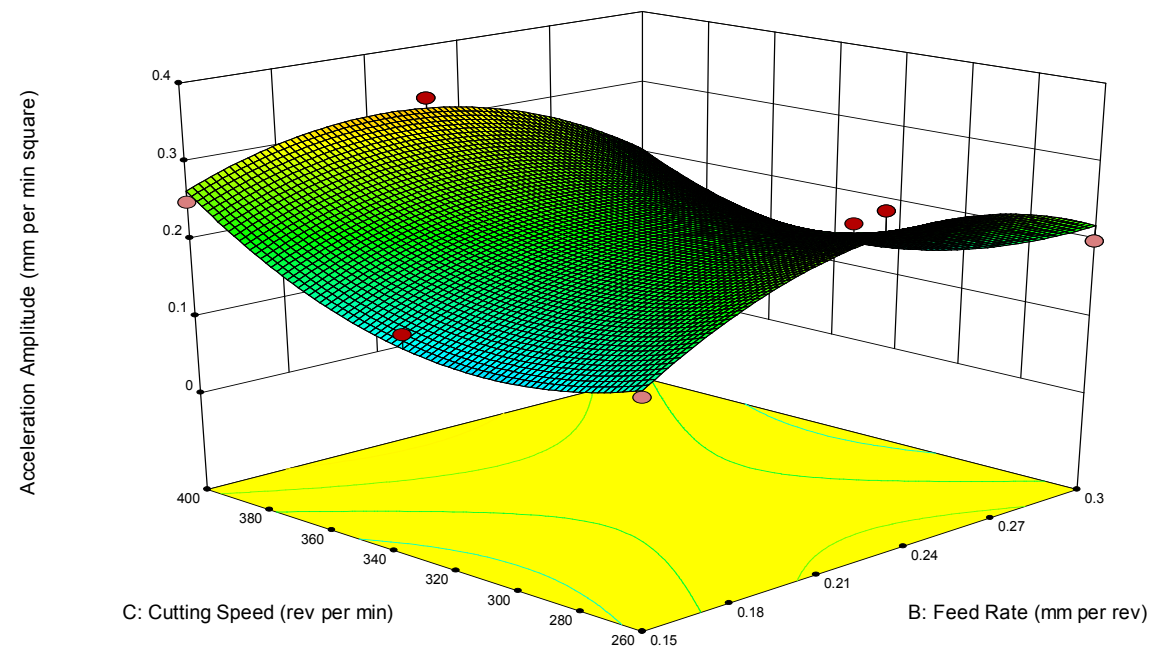

Figure 8. (a) Contour and response surface plots of $V_{i}$ against $B$ and $C$ with $A$ set at $1 \mathrm{~mm}$.

\subsection{Surface Roughness Data}

Table 8 suggests a quadratic regression model to be adequate, and an accurate fit for the surface roughness data. In comparison with other listed models, it records a standard deviation of 0.61 , PRESS of 15.31, R-square value of 0.9749 , adjusted R-square value of 0.9615 , and predicted R-square value of 0.9398 . Table 9 shows the model to be significant for accurate prediction of the surface roughness $\left(R_{a}\right)$ within the selected design limits of $\mathrm{A}, \mathrm{B}$ and $\mathrm{C}$. It also shows the model terms, $\mathrm{B}, \mathrm{C}, \mathrm{AB}, \mathrm{AC}, \mathrm{A}^{2}$ and $\mathrm{C}^{2}$ to be significant. The dominance of influence of $\mathrm{A}, \mathrm{B}$ and $\mathrm{C}$ on $R_{a}$ begins with $\mathrm{B}$, followed by $\mathrm{C}$, and then, $\mathrm{A}$, for the linear terms. It starts with
$\mathrm{AC}$, followed by $\mathrm{AB}$, and then, $\mathrm{BC}$, for the cross-product terms. It also emanates with $\mathrm{A}^{2}$, followed by $\mathrm{C}^{2}$, and then, $\mathrm{B}^{2}$, for the square terms. Table 10 reveals the predicted $\mathrm{R}$-square value of 0.9398 to be in reasonable agreement with the adjusted R-square value of 0.9615 , since the difference of 0.0217 is less than 0.2 . The adequacy precision of 29.644 , greater than 4 , is a desirable signal to noise ratio. There is therefore indication of adequate signal, and of a model that can be used to navigate the design space. The models for the surface roughness $\left(R_{a}\right)$, given in terms of the coded and actual factors A, B and C are as follows:

$$
\begin{aligned}
R_{a} & =4.79+0.23 A+1.32 B-0.63 C+0.85 A B+3.28 A C+0.04 B C+2.94 A^{2}+0.5 B^{2}+1.72 C^{2} \\
R_{a} & =67.90158-23.62775 A-36.62862 B-0.28959 C+11.30778 A B \\
& +0.046801 A C+0.0075873 B C+2.93689 A^{2}+89.66914 B^{2}+0.0003517 C^{2}
\end{aligned}
$$

\begin{tabular}{|c|c|c|c|c|c|c|}
\hline & Standard & & Adjusted & Predicted & & \\
\hline Source & Deviation & R-Squared & R-Squared & R-Squared & PRESS & \\
\hline Linear & 3.06 & 0.1543 & 0.0440 & -0.2195 & 309.94 & \\
\hline $2 \mathrm{FI}$ & 1.97 & 0.6951 & 0.6037 & 0.4362 & 143.29 & \\
\hline Quadratic & 0.61 & 0.9749 & 0.9615 & 0.9398 & 15.31 & Suggested \\
\hline Cubic & 0.73 & 0.9790 & 0.9454 & 0.8300 & 43.21 & Aliased \\
\hline
\end{tabular}

Table 8. Model summary statistics.

\begin{tabular}{|c|c|c|c|c|c|c|}
\hline Source & Sum of Squares & Degree of Freedom & Mean Square & F Value & $\begin{array}{l}\text { p-value } \\
\text { Prob }>\text { F } \\
\end{array}$ & \\
\hline Model & 247.76 & 9 & 27.53 & 73.24 & $<0.0001$ & significant \\
\hline A-Tool Nose Radius & 0.99 & 1 & 0.99 & 2.64 & 0.1228 & \\
\hline B-Feed Rate & 31.13 & 1 & 31.13 & 82.82 & $<0.0001$ & \\
\hline C-Cutting Speed & 7.11 & 1 & 7.11 & 18.91 & 0.0004 & \\
\hline $\mathrm{AB}$ & 8.63 & 1 & 8.63 & 22.96 & 0.0002 & \\
\hline $\mathrm{AC}$ & 128.79 & 1 & 128.79 & 342.65 & $<0.0001$ & \\
\hline $\mathrm{A}^{\wedge} 2$ & 51.75 & 1 & 51.75 & 137.68 & $<0.0001$ & \\
\hline $\mathrm{B}^{\wedge} 2$ & 1.53 & 1 & 1.53 & 4.06 & 0.0600 & \\
\hline $\mathrm{C}^{\wedge} 2$ & 17.82 & 1 & 17.82 & 47.40 & $<0.0001$ & \\
\hline Residual & 6.39 & 17 & 0.38 & & & \\
\hline Cor Total & 254.15 & 26 & & & & \\
\hline
\end{tabular}

Table 9. ANOVA for response surface quadratic model for surface roughness. 
Table 10. Quadratic model statistics.

\begin{tabular}{llll}
\hline Standard Deviation & 0.61 & R-Squared & 0.9749 \\
Mean & 8.24 & Adjusted R-Squared & 0.9615 \\
C.V. \% & 7.44 & Predicted R-Squared & 0.9398 \\
PRESS & 15.31 & Adequacy Precision & 29.644 \\
\hline
\end{tabular}

Figure 9a shows how well the predicted $R_{a}$ data fits the actual data. Figure $9 \mathrm{~b}$ shows $R_{a}$ to have nonlinear relationship with $\mathrm{A}, \mathrm{B}$ and $\mathrm{C}$. It also shows the influence of $\mathrm{A}$ and $\mathrm{C}$ on $R_{a}$ to be significant at low and high levels of their values, whereas that of $\mathrm{B}$ on $R_{a}$ is shown to be significant only at high level of its value. It should be noted that $R_{a}$ decreased to the reference point as $\mathrm{A}$ and $\mathrm{C}$ increased, and then, increased, whereas it increased continuously as B increased. These behaviors have the implication of $R_{a}$ being minimized when $\mathrm{A}$, and $\mathrm{C}$ are set at the intermediate level of their values, whereas $\mathrm{C}$ is set at the extreme low level of its value. They can also be seen in the contour and response surface plots given in Figs 10 to 12, and attributed to the observed interactions of the process variables, A, B and C.

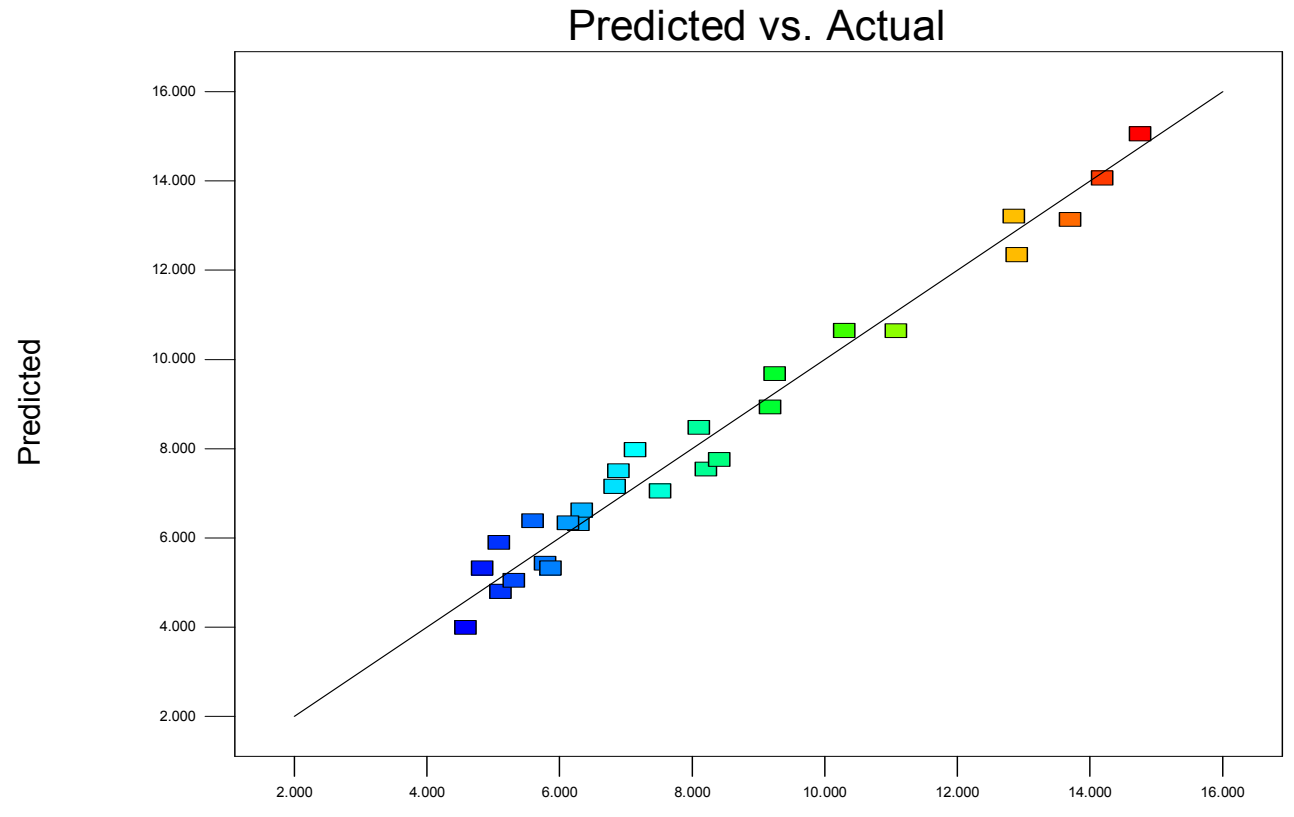

Actual

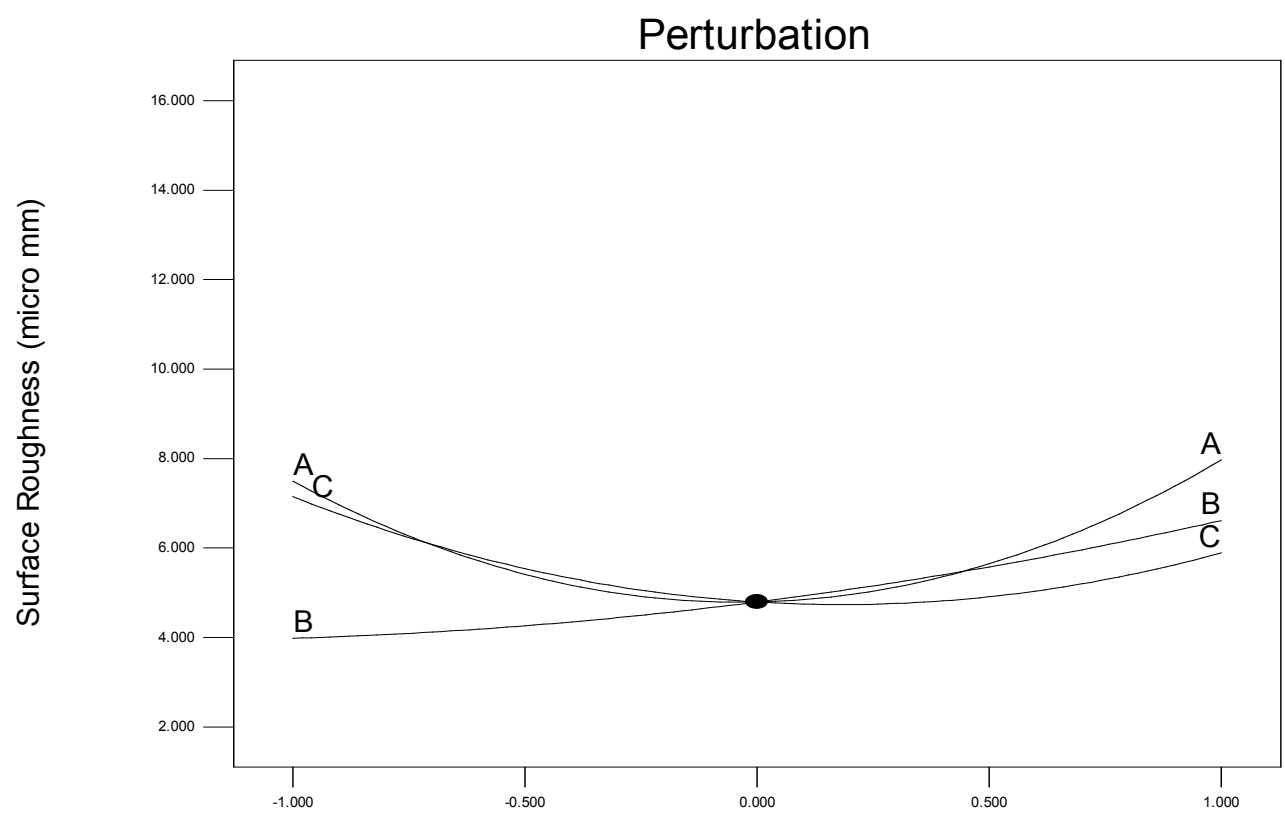

Deviation from Reference Point (Coded Units)

Figure 9. (a) Predicted vs actual, and perturbation plots for $R_{a}$. 


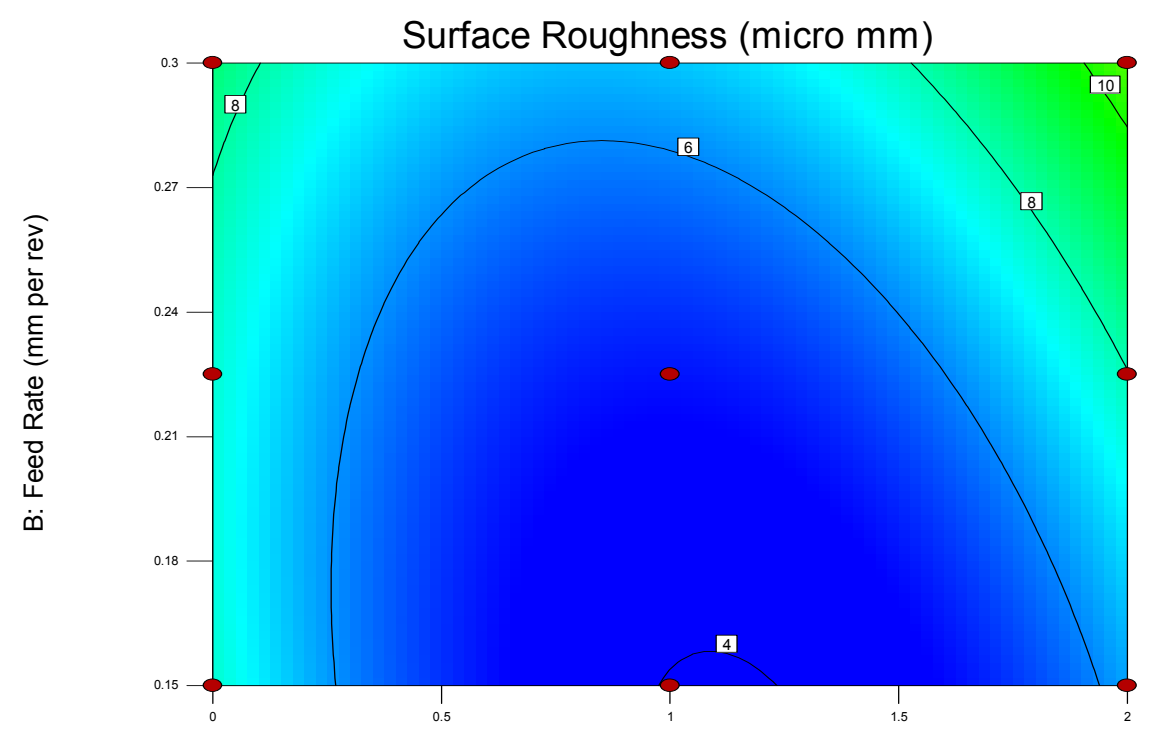

A: Tool Nose Radius (mm)

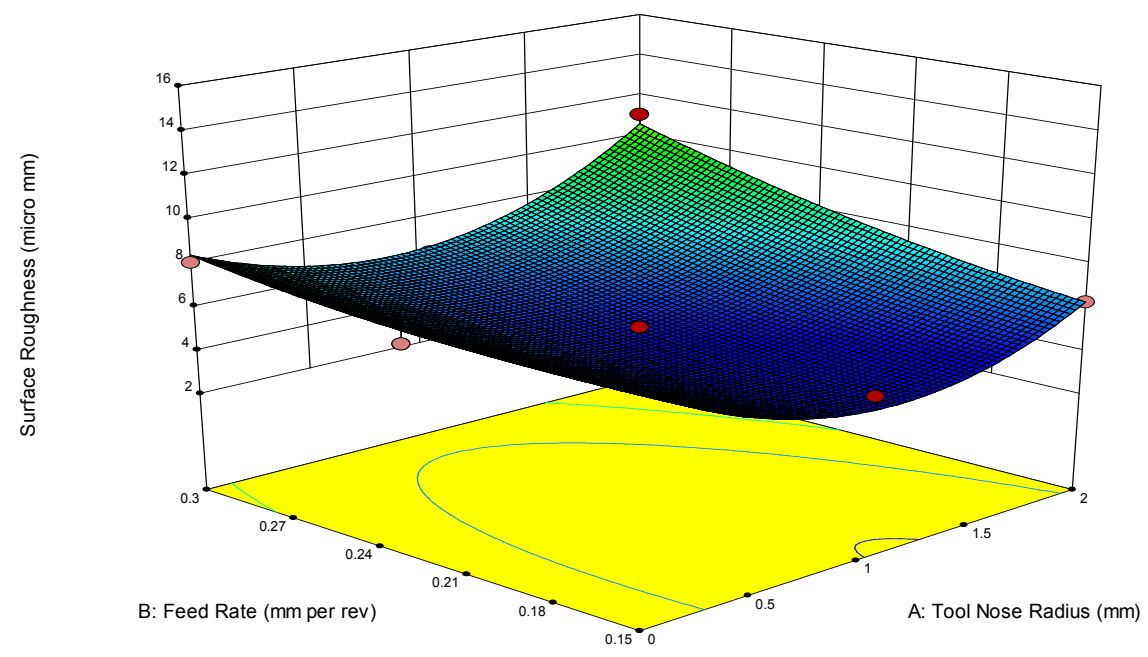

Figure 10. Contour and response surface plots of $R_{a}$ against $A$ and $B$ with $C$ set at 330 rev per min.

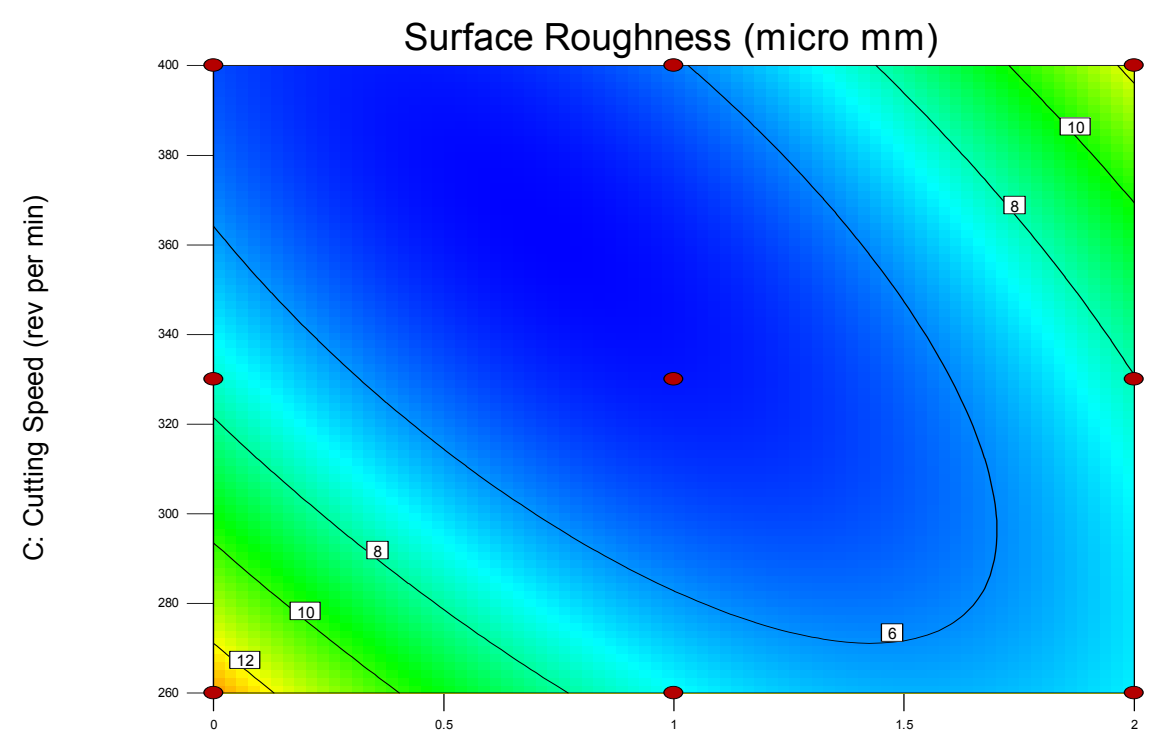

A: Tool Nose Radius (mm) 

Alloy Steel Using Response Surface Methodology

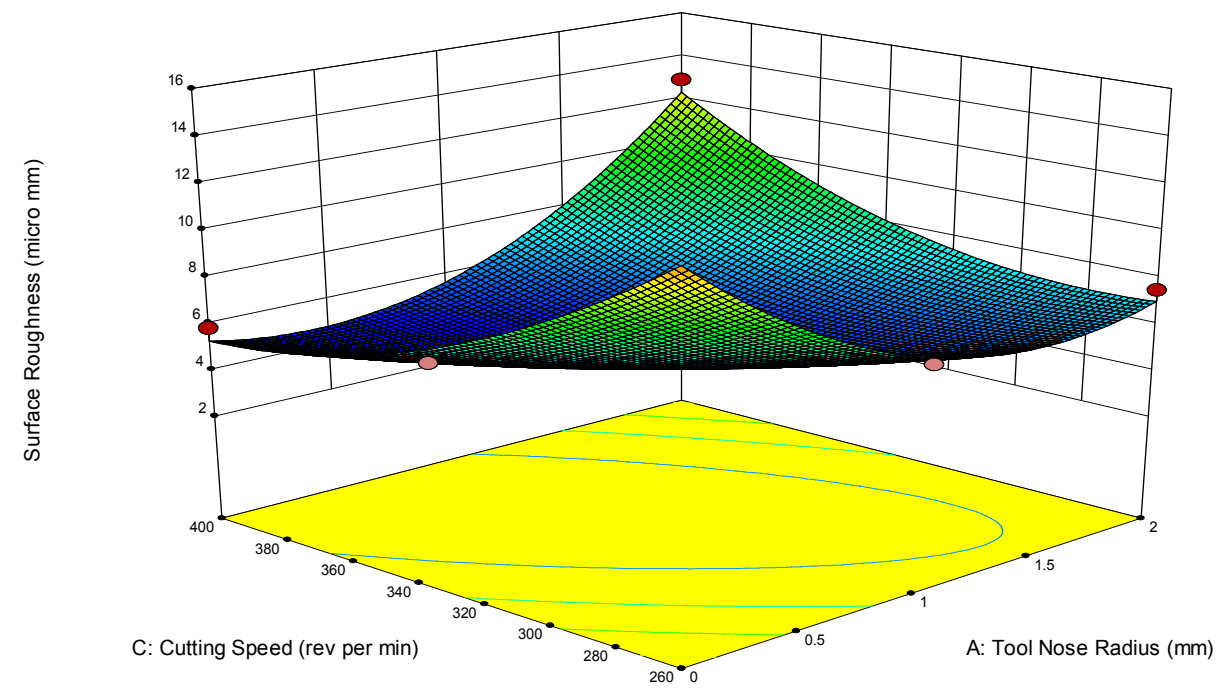

Figure 11. Contour and response surface plots of $R_{a}$ against $A$ and $C$ with $B$ set at $0.225 \mathrm{~mm} / \mathrm{rev}$.

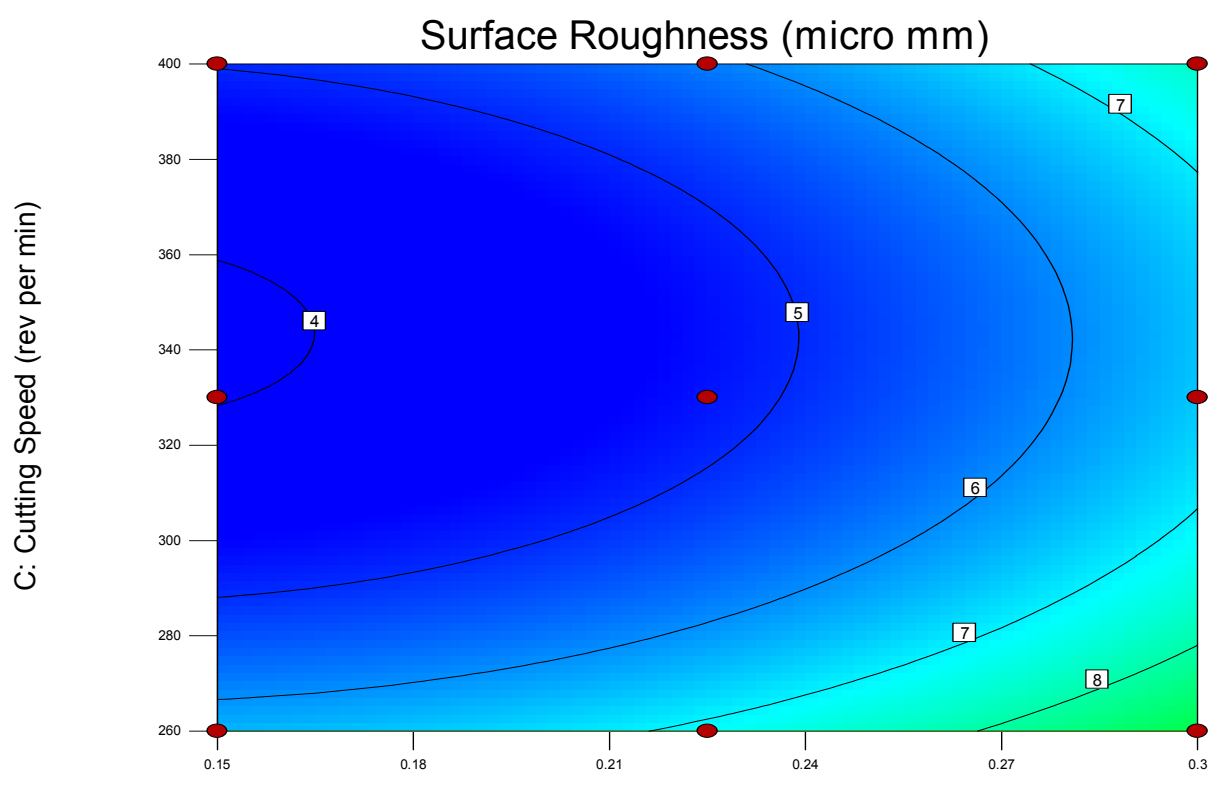

B: Feed Rate (mm per rev)

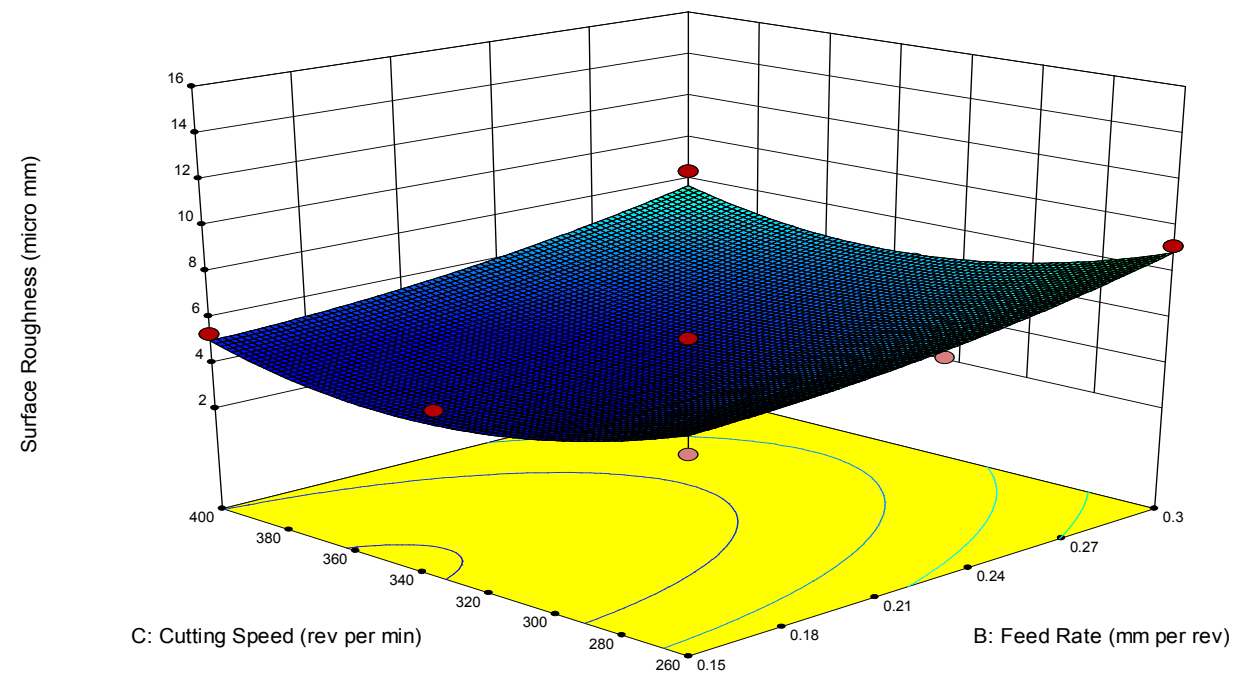

Figure 12. Contour and response surface plots of $R_{a}$ against $B$ and $C$ with $A$ set at $1 \mathrm{~mm}$. 


\subsection{Parameter Optimization}

The surface roughness $\left(R_{a}\right)$, and the machining induced vibration $\left(V_{i}\right)$ are both undesirable and uncontrollable quality characteristics of a turning process. As such, they are to be minimized to improve on product quality subject to constraints determined by the design limits of the process variables. Figure 13, therefore, gives the optimum setting of

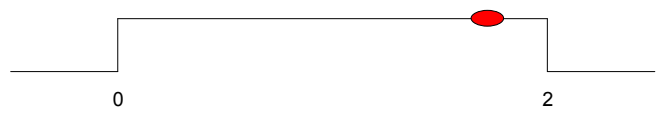

A:Tool Nose Radius $=1.72301$

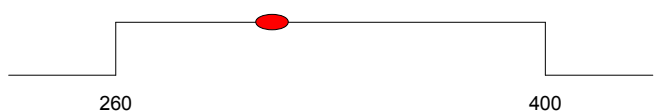

C: Cutting Speed $=311.075$

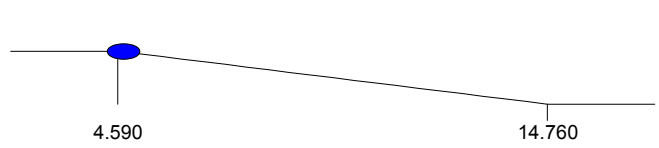

Surface Roughness $=4.740$
$\mathrm{A}$ as $1.72301 \mathrm{~mm}, \mathrm{~B}$ as $0.15 \mathrm{~mm} / \mathrm{rev}$, and $\mathrm{C}$ as 311.075 $\mathrm{rev} / \mathrm{min}$. These would be required to minimize $V_{i}$ to a value of $0.08 \mathrm{~mm} / \mathrm{s}^{2}$ and $R_{a}$ to a value of $4.74 \mu \mathrm{mm}$ with desirability of 0.948 , all within the selected design space. This is confirmed by the contour and surface plots of Figs 6 to 8 and Figs 10 to 12 .

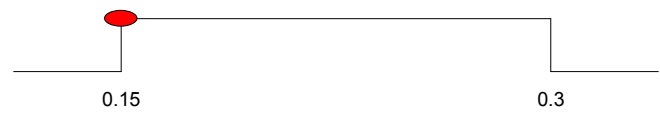

B:Feed Rate $=0.15$

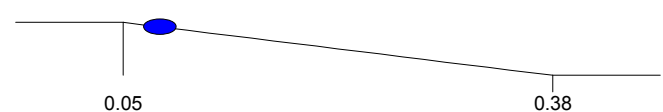

Acceleration Amplitude $=0.08$

Desirability $=0.948$

Figure 13. Results of parameter optimum.

\subsection{Surface Roughness Versus Machining Induced Vibration}

The machining induced vibration $\left(V_{i}\right)$ should have influence on surface roughness $\left(R_{a}\right)$ as excess of it impacts negatively on the cutting zone in a turning operations. However, a nonlinear relationship is observed in the plot of $R_{a}$ versus $V_{i}$ (Fig. 14). The R-square value of 0.1282 indicates there is no significant correlation between these process characteristics within the experimental design limits. However, there may be correlation outside these limits.

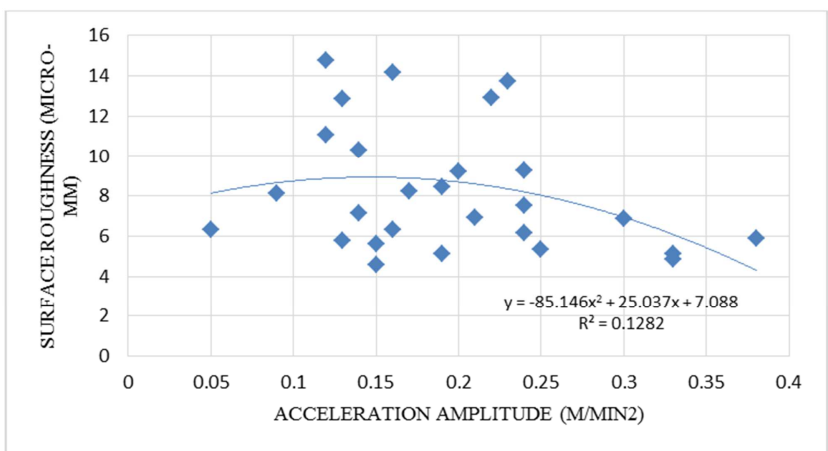

Figure 14. A plot of $R_{a}$ against $V_{i}$.

\section{Conclusion}

Modeling, prediction and optimization of the machining induced vibration of the cutting tool, and the surface roughness of the work-piece as functions of the tool nose radius, feed rate and cutting speed has been undertaken. Response surface methodology, based on the central composite design of experiment was used in a turning experiment in which $41 \mathrm{Cr} 4$ alloy special steel was turned on a conventional lathe with standard cutting tool, and the response parameters measured. Analyses and optimization of the generated response characteristics data was performed using the Design Expert version 9.0.6.2 software. The following conclusion was reached.

a. The selected process and quality characteristics can accurately be predicted within limits of the tool nose radius, feed rate, and the cutting speed using the developed regression models.

b. The machining induced vibration data fits well with a quadratic regression model. The relationship of the machining induced vibration with each of the tool nose radius, feed rate and cutting speed is nonlinear. In terms of significance, the effect of the tool nose radius and cutting speed on the machining induced vibration is more at low and high levels of their values, when compared to that of feed rate. The machining induced vibration would be minimized when the tool nose radius is set at higher level of its values; the feed rate is set at either lower or higher level of its values; and the cutting speed is set at the reference point.

c. Again, the surface roughness data for the work-piece fits well with a quadratic regression model. Its relationship with each of the tool nose radius, feed rate 
and cutting speed is nonlinear. The influence of tool nose radius and cutting speed on surface roughness is significant at low and high levels of their values, whereas that of feed rate on surface roughness is significant only at high level of its value. The surface roughness is minimized when the tool nose radius and cutting speed are set at their intermediate values, and the feed rate set at its extreme low value.

d. Within the selected design space, the optimum setting of the tool nose radius at $1.72301 \mathrm{~mm}$, feed rate at 0.15 $\mathrm{mm} / \mathrm{rev}$, and cutting speedat $311.075 \mathrm{rev} / \mathrm{min}$, would minimize $V_{i}$ to a value of $0.08 \mathrm{~mm} / \mathrm{min}^{2}$ and $R_{a}$ to a value of $4.74 \mu \mathrm{mm}$ with desirability of 0.948 .

e. There is a nonlinear relationship, and no significant correlation between the surface roughness and the machining induced vibration. This is suggested by the $\mathrm{R}$-square value of 0.1982 . However, there may be correlation outside the limits of the selected process variable.

\section{References}

[1] Aggarwal, A. and Singh, H., Optimization of Machining Techniques - A retrospective and literature review, Sadhana, Vol. 30, Part 6, 2005, 699-711.

[2] Kumar, N. and Uppal, N., A Review on Various Optimization Techniques used in Turning Operation for Improving Surface Roughness, Mechanica Confab, Vol. 2, No. 4 (2013) 45-51.

[3] Ozcakar, N. and Kasapogu, O. A., Modeling of Surface Roughness in Machining, Yontim, Yil 20, Saya 64, 2009, 2740 .

[4] Abhang, L. B. and Hameedullah, M., Power Prediction Model for Turning EN-31 Steel Using Response Surface Methodology, Journal of Engineering Science and Technology Review, Vol. 3, No. 1, 2010, 116-122.

[5] Sahoo, P., Optimization of Turning Parameters for Surface Roughness using RSM and GA, Advances in Production Engineering and Management, Vol. 6, No. 3, 2011, 197-208.

[6] Abhang, L. B. and Hameedullah, M., Optimization of Power Consumption by Desirability Function Approach, International journal on Resent Trends in Engineering and Technology. Vol. 6, No. 2, 2011, 287-290.

[7] Sastry, M. N. and Devi, K. D., Optimization of Performance Measures in CNC Turning using Design of experiment (RSM), Science Insight: An International Journal, Vol.1, No. $1,2011,1-5$.

[8] Srinivasan, A., Arunachalam, R. M., Ramesh, S. and Senthilkumaar, J. S., Machining Performance Study on Metal matrix Composites - A Response Surface Methodology Approach, American Journal of Applied Science, Vol. 9, No. 4, 2012, 478-483.

[9] Ramudu, C. and Sastry, M. N., Analysis and Optimization of Turning Process Parameters using Design of Experiment, International journal of Engineering Research and Applications, Vol. 2, issue 6, 2012, 020-027.

[10] Aruna, M. and Dhanalaksmi, V., Design Optimization of Cutting Parameters when Turning Inconel 718 with Cermet
Inserts, International Journal of Mechanical and Aerospace Engineering, vol. 6, 2012, 187-190.

[11] Chomamutr, K. and Jongprasithporn, S., Optimization Parameters of Tool Life Model using the Taguchi Approach and Response Methodology, International Journal of Computer Science Issues, Vol. 9, Issue 1, No. 3, 2012, 120 125 .

[12] Abhang, L. B. and Hameedullah, M., Optimal Machining Parameters for Achieving the Desired Surface Roughness in Turning of Steel, Technical Journal of Engineering Research (TJER), Vol. 9, No. 1, 2013, 37-45.

[13] Manu, R., Akbar, B. S., and Sharmas, V. S., Predictive Machinability Model of Hardened Steel Material in Turning Operation by Response Surface Regression Method, International Journal of Applications or Innovation in Engineering and Management, Vol. 2, Issue 10, 2013, 330334.

[14] Makadia, A. J. and Nanavati, J. I., Optimization of Machining Parameters for Turning Operations Based on Response Surface Methodology, Measurement, Elsevier, Vol. 46, 2013, $1521-1529$.

[15] Kannan, A., Esakkiraja, K. and Mataraj, M., Modeling and Analysis for Cutting Temperature in Turning of Aluminium 6063 using Response Surface Methodology, Journal of Mechanical and Civil Engineering, Vol. 9, Issue 4, 2013, 5964.

[16] Phate, M. and Tatwawadi, V. H., Formulation of a Field Data Based Model for a surface Roughness using Response Surface Method, International Journal of Science, Engineering and Technology Research, Vol. 2, Issue 4, 2013, 793-798.

[17] Bhulyan, T. H. and Ahmed, I., Optimization of Cutting Parameters in Turning Process, Journal of Production Engineering, Vol. 16, No. 2, 2013, 11-19.

[18] Manohar, M., Joseph, J., Selvaraj, T. and Sivakumar, D., Application of Box Behnken Design to Optimize the Parameters for Turning Inconel 718 using Carbide Tools, International Journal of scientific and Engineering Research, Vol. 4, Issue 4, 2013, 620-642.

[19] Thiyagu, M., Karunamoorthy, L. and Arunkumar, N., Experimental Studies in machining Duplex Stainless Steel using Response Surface Methodology, International Journal of Mechanical Engineering, Vol. 14, No. 3, 2014, 48-61.

[20] Saini, P. and Parkash, S., A Multi Response Optimization of Machining Parameters for Surface Roughness and MRR in High Speed CNC Turning of EN-24 Alloy Steel using Response Surface Methodology, International Journal of Engineering Science and Research Technology, Vol. 3, Issue 9, 2014, 333-345.

[21] Saini, P., Parkash, S. and Choudhary, D., Experimental Investigation of Machining Parameters for Surface Roughness in High Speed CNC Turning of EN-24 Alloy Steel using Response Surface Methodology, International Journal of Engineering Research and Applications, Vol. 4, Issue 5, 2014, $153-160$.

[22] Soni, V., Mondal, S. and Singh, B., Process Parameters Optimization in Turning of Aluminum using a New Hybrid Approach, International Journal of Innovative Science, Engineering, and Technology, Vol. 1, Issue 3, 2014, 418-423. 
[23] Shunmugesh, K., Panneerselvam, K. and Amal, G., Optimization of Turning Parameters with Carbide Tool for Surface Roughness Analysis using Response Surface Methodology, International journal of research in Aeronautical and Mechanical Engineering, Vol. 2, Issue 6, 2014, 17-27.

[24] Kumar, M. S., A Detailed Comparison among Dry, Wet and Gas Cooled Machining of Super Duplex Stainless Steel, Global Journal of Researches in Engineering: A Mechanical and Mechanics Engineering, Vol. 14, Issue 7, 2014, 17-25.

[25] Sastry, M. N., Devi, K. D. and Reddy, K. M., Analysis and Optimization of machining Parameters using Design of Experiments, Industrial Engineering Letters, Vol. 2, No. 9,2012, 23-32.

[26] Revankar, G. D., Shetty, R., Rao, S. S., and Gaitonde, V. N., Response Surface Model for Surface Roughness during Finish Turning of Titanium Alloy under Minimum Quantity Lubrication, International Conference on Emerging Trends in Engineering and Technology, Dec. 7 -8, 2013, 78-84.

[27] Mahajan, C. K., Mote, M. L., Patil, B. V. and Patil, H. G., Formulation and Simulation of a Field Data Based Model for the Turning process by using Response Surface Method, International Journal of Advanced Scientific and Technical Research, Vol. 2, Issue 3, 2013, 355-370.

[28] Shihab, S. K., Khan, Z. A., Mohammad, A. and Siddiquee, A. N., Optimization of Surface Integrity in Dry Hard Turning using RSM, Sadhand, Vol. 39, Part 5, 2014, 1035-1053.

[29] Gupta, U. and Kohi, A., Experimental Investigation of Surface Roughness in Dry Turning of AISI 4340 Alloy Steel using PVD- and CVD-Coated Carbide Inserts, International Journal of Innovations in Engineering and Technology, Vol. 4, Issue 1, 2014, $94-103$

[30] Khan, M. A., Kittur, J. K. and Kohir, V. D., Study and Analysis of Effect of Cutting Parameters on Cutting Forces and Surface Roughness, Advanced Engineering and Applied Sciences,: An International Journal, vol. 5, No. 3, 2015, 63 73

[31] Devkumar, V., Sreedhar, E. and Prabakaran, M. P., Optimization of Machining Parameters on AL 6061 Alloy using Response Surface methodology, International Journal of Applied Research, Vol. 1, No. 7, 2015, 01-04.

[32] Devi, K. D., Babu, K. S. and Reddy, K. H., Mathematical Modeling and Optimization of Turning process Parameters using Response Surface Methodology, International Journal of Applied Science and Engineering, Vol. 13, No. 1, 2015, 5568.

[33] Rajpoot, B. S., Moond, D. R. and Shrivastava, S., Investigating the effect of Cutting Parameters on the Average Surface Roughness and materials Removal Rate during Turning of Metal Matrix Composite using Response Surface Methodology, International Journal on Recent and Innovation
Trends in Computing and Communication, Vol. 3, Issue 1, 2015, 241-247.

[34] Khidhir, B. A., A-Oqaiel, W. and Kareem, P. M., Prediction Models by Response Surface Methodology for Turning Operation, American Journal of Modeling and Optimization, Vol. 3, No. 1, 2015, 1-6.

[35] Agrawal, S., Guar, M. K., Kasdekar, D. K., Agrawal, S. and Malvi, C. S., Optimal Machining Condition for Turning of Hard Porcelain using Response Surface Methodology, European Journal of Advances in Engineering and Technology, Vol. 2, No. 5, 2015, 44-51.

[36] Ranganath, M. S., Vipin, Kumar, N., and Kumar, R., Experimental Analysis of Surface Roughness in CNC Turning of Aluminum using Response Surface Methodology, International Journal of Advanced Research and Innovation, Vol. 3, Issue 1, 2015, 45-49.

[37] Chandra, B. S. and Prasad, M. V. R. D., Parameter Optimization while Dry Turning AISI 1045 Steel using CBN Tool by Response Surface Methodology, GE International Journal of Engineering Research, Vol. 3, Issue 7, 2015, 69-82.

[38] Kassab, S. Y. and Khoshnaw, Y. K., The Effect of Cutting Tool Vibration on Surface Roughness of Work-piece in Dry Turning Operation, Engineering and technology, Vol. 25, No. 7, 2007, 879-889.

[39] Han, X., Wang, M. and Ouyang, H., Vibration of Work-Pieces during Turning Operations, Journal of Physics: Conference Series 181, http://iopscience.iop.org/1742-6596/181/1/012032, 2009, 1-7.

[40] Cahuc, O., K'nevez, J Y., Gerard, A., Darnis, P., Albert, G., Bisu, C. F., and Gerard, C., Self-Excited Vibrations in Turning: Cutting Moment Analysis, International Journal of Advanced manufacturing Technology, version 1-9, 2010, 19.

[41] Delijaicov, S., Leonardi, F., Bordinassi, E. C., and Batalha, G. F., Improved Model to predict Machined Surface Roughness based on the Cutting Vibrations signal during Hard Turning, Archives of Materials Science and Engineering, Vol. 45, Issue 2, 2010, 102-107.

[42] Rogov, V. A. and Siamak, G., Optimization of Surface Roughness and Vibration in Turning of Aluminum Alloy AA2024 Using Taguchi Technique, International Journal of Mechanical, Aerospace, Industrial, Mechatronic and Manufacturing Engineering Vol. 7, No. 11, 2013, 2330-2339.

[43] Rogov, V. A. and Siamak, G., The Effect of Tool Construction and Cutting Parameters on Surface Roughness and Vibration in Turning of AISI 1045 Steel Using Taguchi Method, Modern Mechanical Engineering, 4, 2014, 8-18. 